\title{
The Construction and Realisation of Geographic Brand Rent in New Zealand Wine
}

\author{
David Hayward and Nicolas Lewis
}

\begin{abstract}
David J. Hayward, School of Geography, Geology \& Environmental Science, The University of Auckland, Auckland, New Zealand (d.hayward@auckland.ac.nz)

Nicolas Lewis, School of Geography, Geology \& Environmental Science, The University of Auckland, Auckland, New Zealand (n.lewis@auckland.ac.nz)
\end{abstract}

\begin{abstract}
This paper examines the concept of geographic brand rent in production and marketing of New Zealand wine. It is argued that the region of origin for fine wine is not only a recognised feature of its value but that this may be conceived as a form of brand rent and furthermore that it is measurable. The analysis uses both cross-sectional and longitudinal approaches to consider grape and vineyard land prices, as well as interviews with industry informants to explore wine company strategies. Explicit use is made of the value-added chain in order to identify and situate the construction of rents and the positionality of industry actors in respect to these. The analysis highlights the quest to control different forms of brand rent that have led the restructuring of the wine industry. It also exposes countervailing pressures towards economic resilience and market vulnerability facing the fine wine industry.
\end{abstract}

Keywords: wine, wine industry, geographic brand rent, New Zealand

\section{Introduction}

In this paper we seek to isolate the specific contribution of geographic identity to the value of a processed agricultural product. From a value chains perspective simple agricultural commodities may be disassembled conceptually into discrete labour and capital inputs occurring along the production sequence from raw materials to finished product. Qualitatively differentiated products however, pose a particular challenge since they necessarily incorporate other factors, and if the returns for otherwise similar commodities differ then we may infer that their qualitative differences impart discrete value components. Geographic identity may be one such component, and the contribution of region and place to the construction of value is the focus of this analysis.

The products of the global wine industry are highly differentiated by geographical identities - chiefly the regions of origin for the principal raw material: grapes. Considerable research efforts have explored the environmental and cultural factors that contribute to geographically differentiated wine products, and there is ample evidence that geographical identity contributes to the prices of wine products. This paper explores the contribution of geographic identity in production and marketing of New Zealand wine. We argue that the region of origin is not only a recognised feature of fine wine but that it is a measurable component of a wine commodity's value, and hence may be conceived as a form of brand rent.

\section{Growth and Change in the New Zealand Wine Industry}

The New Zealand wine industry has undergone some rapid and profound changes in a relatively short period of time. In both magnitude and form these have accompanied a reorientation of the industry towards the production and export of its 
globally-distinctive wine products in which the national and regional geographic identities have been prominent (Barker et al. 2001, Banks et al. 2007, Lewis 2008). The growth of the industry is depicted by Figure 1, which illustrates the rapid expansion of vineyard area since 2000. The regional geography of grape production has shifted markedly too, with a relative shift towards the southern wine-producing regions and in particular, Marlborough.

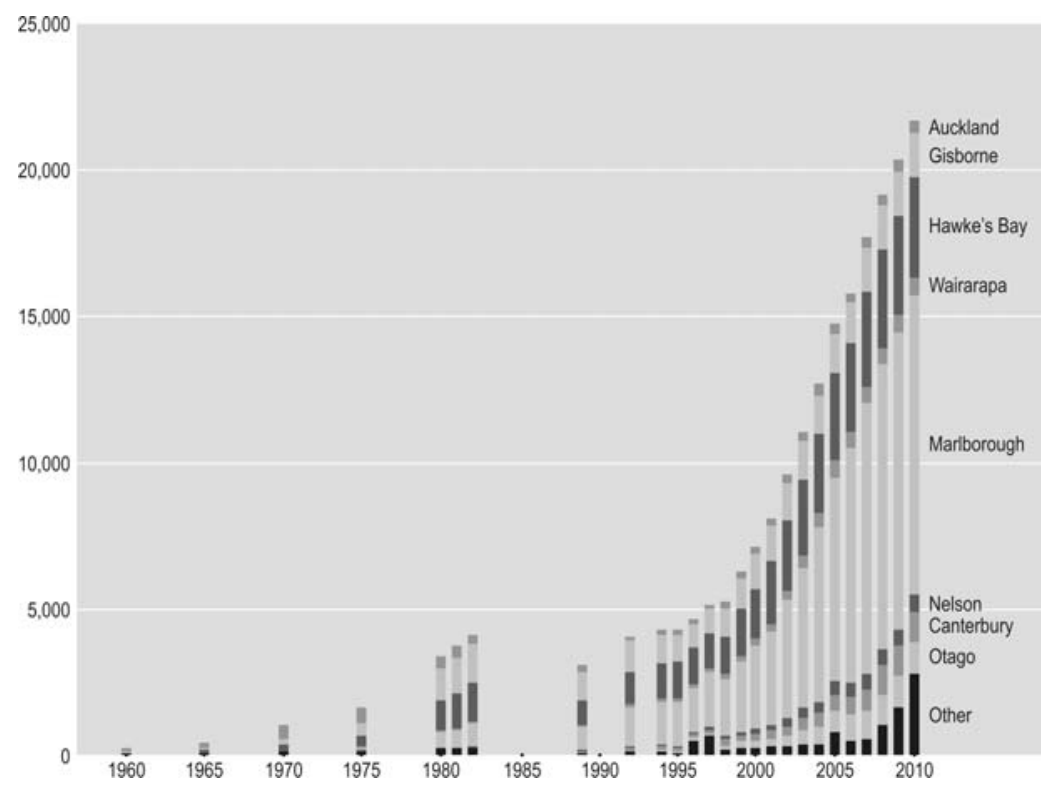

Figure 1: New Zealand Vineyard Area by Region, 1960-2010.

By all measures the national industry has grown rapidly and some of the dimensions of this are revealed in Figure 2. While both vineyard area and the volume of wine produced have increased significantly, exports have increased by many orders of magnitude - although from a very small base. The industry's focus on exports is revealed in this graph, as is its reorientation towards lower-yielding grapes and highervalued wine - as evidenced by the increasing vertical distance between the lines representing vineyard area and volume of production. Similarly the growing vertical distance between the lines representing the export values and export volumes reveals the increasing per unit revenues of exported wine. In the graph these values have been adjusted for inflation and so provide evidence that New Zealand's wine exports have earned increasing returns over the recent period.

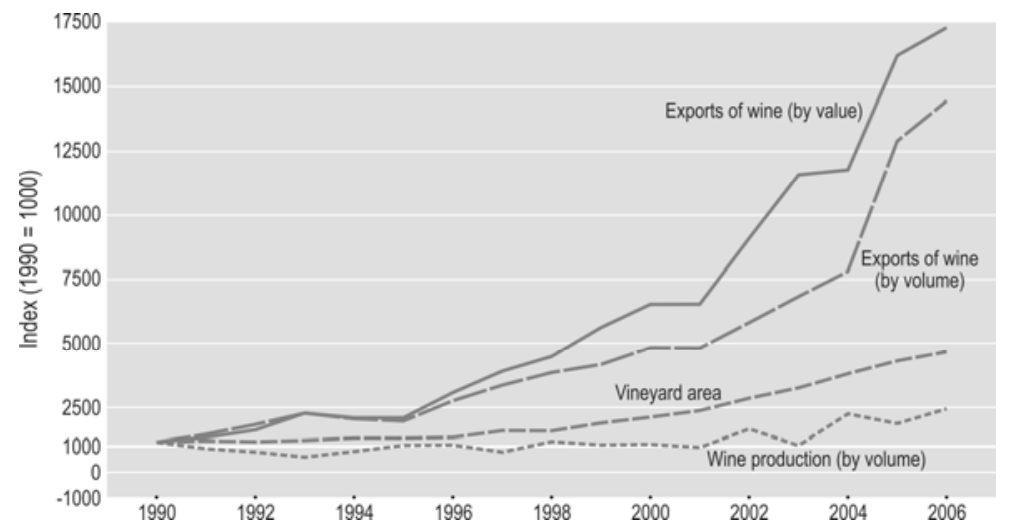

Figure 2: Dimensions of Growth of the New Zealand Wine Industry since 1990. 
Further information on the regional geography of New Zealand wine is given in Table 1, which reveals some characteristics of the main wine-producing regions. Marlborough accounted for $68 \%$ of the total grape harvest by volume in 2008 , and through its relentless growth since 2000 has become the dominant region in most respects. Details are provided in Table 1 for the enterprise and grape variety characteristics of each region. These are relevant to the construction of regional identity which in some cases is closely associated with a particular grape variety, as well as a characterisation of craft versus industrial wine production.

Table 1: Regional Overview of the New Zealand Wine Industry, 2008

\begin{tabular}{|c|c|c|c|c|}
\hline Region & $\begin{array}{l}\text { Number of } \\
\text { Grape - } \\
\text { growers }\end{array}$ & $\begin{array}{l}\text { Grape production } \\
\text { (tonnes) }\end{array}$ & $\begin{array}{l}\text { Number of } \\
\text { Wineries }\end{array}$ & Observations \\
\hline Auckland & 38 & 1,604 & 103 & $\begin{array}{l}\text { Region hosts Head Office and } \\
\text { production facilities of national } \\
\text { wineries }\end{array}$ \\
\hline Gisborne & 89 & 23,911 & 22 & $\begin{array}{l}\text { Best known for chardonnay } \\
\text { variety and dominated by } \\
\text { corporate wineries }\end{array}$ \\
\hline Hawke's Bay & 172 & 34,284 & 71 & $\begin{array}{l}\text { Best known for classic red grape } \\
\text { varieties; hosts both national and } \\
\text { independent producers }\end{array}$ \\
\hline $\begin{array}{l}\text { Wairarapa } \\
\text { (aka Martinborough) }\end{array}$ & 44 & 4,105 & 58 & $\begin{array}{l}\text { Best known for pinot noir variety; } \\
\text { and hosts primarily independent } \\
\text { wine producers }\end{array}$ \\
\hline Nelson & 57 & 7,002 & 32 & $\begin{array}{l}\text { No distinct grape variety identity; } \\
\text { hosts primarily independent } \\
\text { producers }\end{array}$ \\
\hline Marlborough & 524 & 194,639 & 109 & $\begin{array}{l}\text { Best known for sauvignon blanc } \\
\text { variety; hosts both national } \\
\text { producers and independent } \\
\text { wineries }\end{array}$ \\
\hline Canterbury & 61 & 6,881 & 54 & $\begin{array}{l}\text { No distinct grape variety identity } \\
\text { but northern district adjacent to } \\
\text { Marlborough; hosts primarily } \\
\text { independent wine producers }\end{array}$ \\
\hline $\begin{array}{l}\text { Otago } \\
\text { (or Central Otago) }\end{array}$ & 75 & 9,495 & 95 & $\begin{array}{l}\text { Best known for pinot noir variety; } \\
\text { and hosts primarily independent } \\
\text { wine producers }\end{array}$ \\
\hline
\end{tabular}

Sources: New Zealand Wine Institute for data.

\section{The Source of Geographic Brand Rent}

In an earlier study of the Marlborough wine region and its iconic variety, sauvignon blanc, we developed the argument that geographic references bundle a number of qualities that are recognised by consumers and thus contribute to market demand (Hayward and Lewis 2008). The foundations for this argument lie in the generally recognised feature of the market for fine wine in which a number of qualitative components contribute to a wine's value (Thrane 2004; Unwin 1999). These acknowledge that wine is an aspirational commodity and consumer demand is greatly 
influenced by subjective qualities reinforced by a range of opinion-forming sources of information, and the consumers' own knowledges of wine. These qualities are coveyed in a number of consumer signals or statements, including but not restricted to labels (Banks et al. 2007, Beverland 2005, Perrouty et al. 2006). The evident recognition of qualitative features such as regional origin, grape variety and even winemakers' brands nonetheless required empirical examination and in the case of Marlborough Sauvignon Blanc we sought to confirm the discrete value contributions of these attributes.

Geographic origin has been demonstrated to be both an independent factor in the price of fine wine (Schamel 2006; Schamel and Anderson 2003) and a factor in consumers' decision-making (Beverland 2005; Perrouty, d'Hauteville, and Lockshin 2006; Tustin and Lockshin 2001). In general, the source of grapes is the principal geographic attribute although the site of processing, regional or local branding, or regional identity of the enterprise also conveys reference to place. Geographic attributes become part of the commodity bundle and, like other brand attributes, becomes a recognised factor in consumers' preferences. Wine is an example of a what has been termed a 'positional good' (Frank 2008, Benjamin et al. 1999) - a commodity that conveys social status (Bourdieu 1989), and a key factor in this is its region of origin. Previous research has focused on the construction of geographic identity in wines through conventions, such as the French appellation system or through collective adherence to a regional style (Moran 1993; Vaudour 2002). However, in our study of Marlborough Sauvignon Blanc (Hayward and Lewis 2008) we argued that the geographic brand enters the value chain as an inalienable, common factor available to all producers. Thus while it may be possible to identify specific labour and capital inputs to create distinctive product the geographic brand is nonetheless a discrete factor in the differentiated wine commodity. For this reason we argued that the value extracted for this geographic factor is therefore a rent - a value earned through the use of the factor, but which is not consumed by the production process nor contributes any transformation of the product (Alchian 2008).

The value chain depicted in Figure 3 identifies the various points at which geographic brand rent may be extracted. Its estimates were derived from the aggregated opinions of representatives of wine enterprises. An important point in this depiction of the wine value chain is that the geographic brand rent is available to enterprises throughout the value chain - including those with no actual presence in the region. However, the key medium for accessing the geographic rent are the regionally-sourced grapes - since these intermediary commodities are axiomatically imbued with the geographic brand. Wine-specific legislation such as the French Appellation d'Origine Controlé or New Zealand's Wine Act exists largely to ensure the authenticity of grapes' geographic origins. Thus for the analytical purpose of measuring geographic brand rent wine grapes are the most appropriate object for study.

The previous estimates for geographic brand rent (Hayward and Lewis 2008) were developed for a single, regional grape variety. In this paper we use a comparative analysis to further explore this factor through an analysis of prices for New Zealand's main grape varieties and grape-producing regions. This involves both cross-sectional and time-series elements: the former through distinguishing between variety and region, and the latter through carrying the analysis over a recent period. Data is taken over a short time period in order to overcome the inherent, short-term variability experienced by all horticultural industries. Following this analysis we consider the strategic activities of New Zealand Winegrowers that have affected the positioning of New Zealand wine as a brand. 


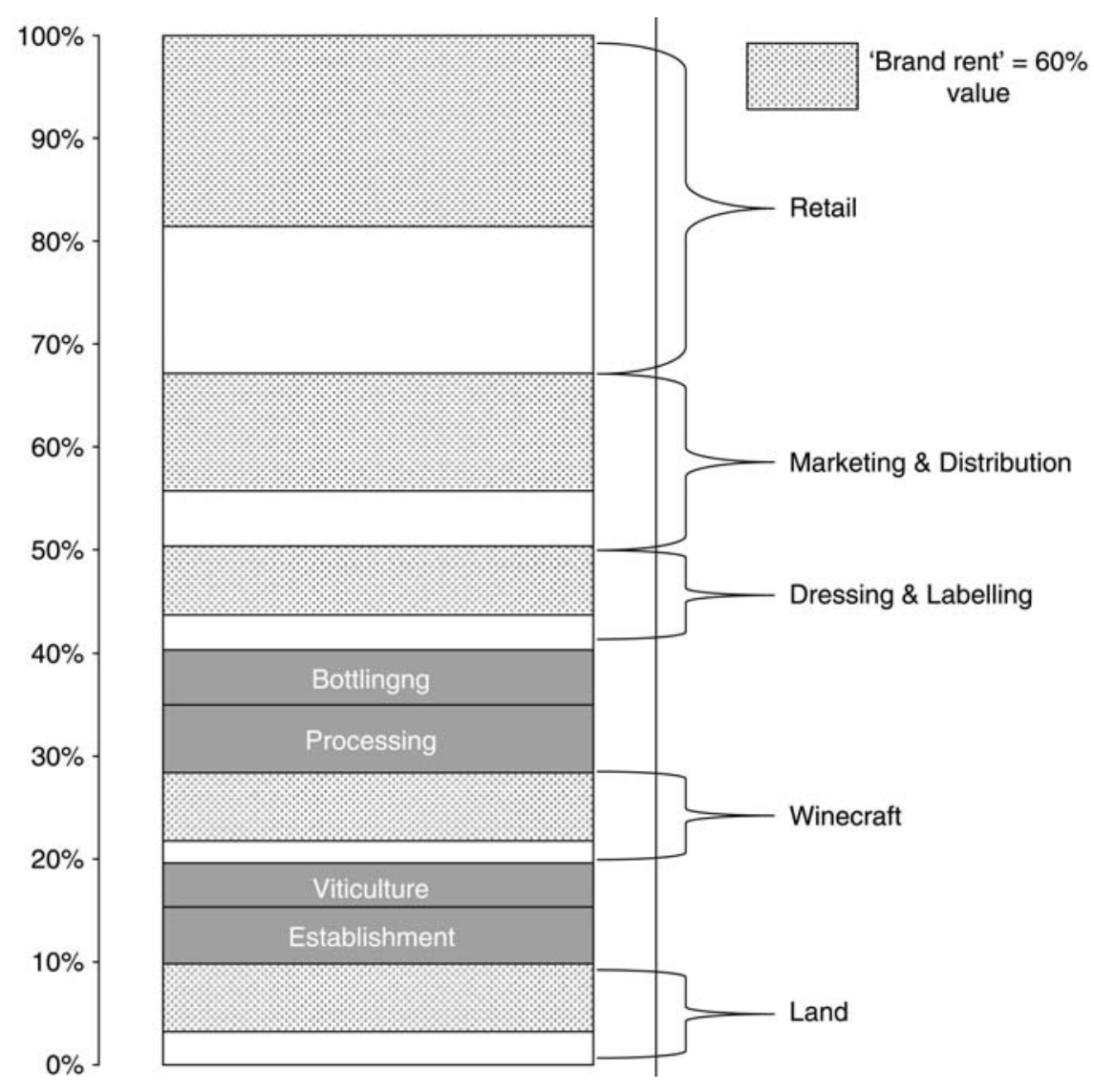

Figure 3: Estimates of Brand Rents in New Zealand Wine Value Chain. Source: Hayward and Lewis (2008).

\section{Grape Prices and Geographic Differentials}

Wine grapes are an intermediary commodity and have no use other than as an input for wine-making. Wine grapes are thus a fully constrained input and hence one may infer that grape prices are therefore an unbiased measure within the context of the wine value chain. The value of wine grapes may nonetheless reflect a number of factors. These include the physical characteristics of the grapes, such as sugar levels, as well as seasonal variability owing to normal supply and demand factors (yield, market demand and so on). The grape variety and its region of origin are two objective factors impacting on price. They impose a determining influence on qualities of the wine produced (hedonic/degustatory and positional), albeit mediated through the effects of viticultural and production practices. The clone of grape variety is also a significant factor, with different clones generating different qualities within the same variety. Our analysis includes region-by-region comparisons of average grape prices over the period 2000-2008 for three of New Zealand's leading grape varieties (and where available, clones). We have excluded the fourth major grape variety, pinot noir, owing to ambiguities in its prices. Pinot noir is used for both table and sparkling wine products and grapes tend to be grown for one or other form, using different clones and harvesting practices. For the purpose of this analysis the pinot noir grape is a less constrained input and a less reliable measure, since the geographic production patterns for the two types of wine necessarily affect inter-regional grape prices. Until recently the published price data did not differentiate between the two and so for this analysis pinot noir has been omitted. 
Grape prices were obtained from the published Statistical Annuals of the New Zealand Winegrowers, the industry organisation mandated to monitor and promote the industry and funded by levies (see Lewis 2008). Prices are given as current values in New Zealand dollars but in this analysis are adjusted to constant, 2008 values using the New Zealand Horticulture Producers Price Index, maintained by Statistics New Zealand, the national statistical office. Average grape prices are used, which suppresses the variability of prices within each region but highlights differences between regions. A more important caveat for this data is to note that these prices are for actual grapegrower to winemaker transactions and so overlook the grapes grown by integrated wineries, for whom the grapes do not enter the market and so no objective price is revealed. Many wine producers will simultaneously purchase grapes even while sourcing from their own, integrated vineyards, and will do so for a range of reasons. However, we believe that the market for traded grapes is dominated by the purchases of larger wineries to make premium, regionally denominated wines. Thus, for the purposes of this analysis the traded grape price data may be presumed to be relevant.

The adjusted average prices for chardonnay grapes are revealed in Figure 4 for five regions and New Zealand as a whole. Gisborne is the largest producer of chardonnay, but closely followed by Hawke's Bay and Marlborough, while Wairarapa and Otago are comparatively very small producers. Over this short period it is clear that there are persistent differences in prices achieved for each region. Gisborne grapes earn lower values than the other regions, while Marlborough and Hawke's Bay earn considerably higher prices, especially the former. The two smaller regions earn the highest average prices but for them the results are less certain owing to the smaller sample sizes. Although there are annual fluctuations the pattern and comparative differences are persistent for the three larger regions.

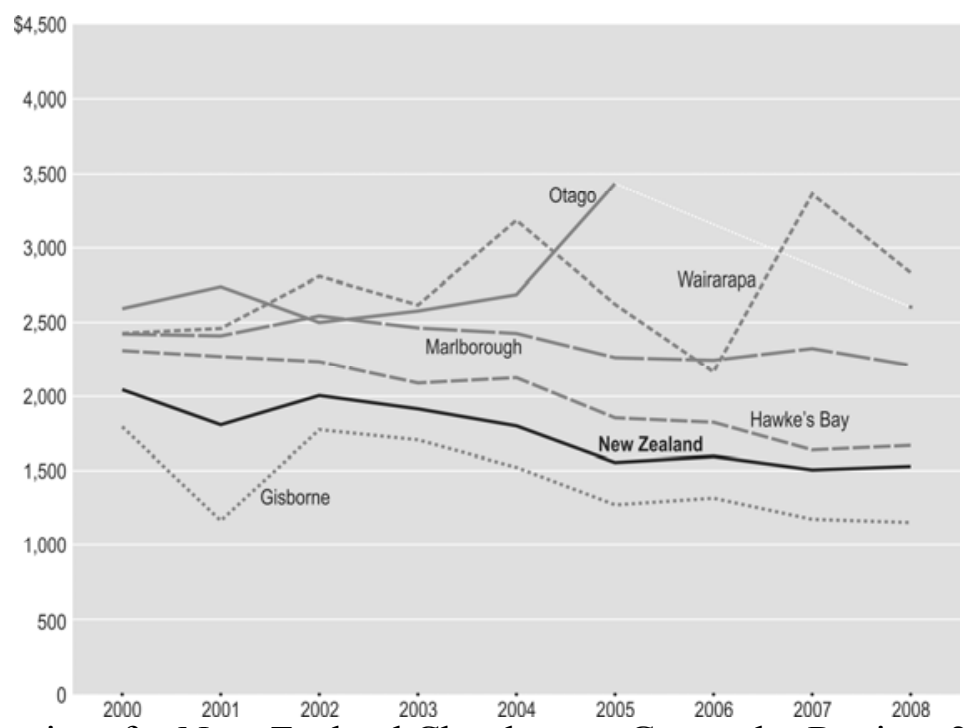

Figure 4: Average prices for New Zealand Chardonnay Grapes by Region, 2000-2008 adjusted to constant, 2008 dollars.

The price data for sauvignon blanc grapes are revealed in Figure 5. For this variety Marlborough is the dominant source and hence the value for NZ as a whole is similar - although notably lower - than for that region. Hawke's Bay and Wairarapa produce substantial volumes but the other two regions are minor producers of this grape variety. As before however, there are substantial and persistent differences between the regions, with Hawke's Bay and Gisborne earning much lower values. Figure 6 shows the equivalent prices for the merlot grape variety. This is an important variety for 
Hawke's Bay and owing to its importance as a regional producer its price tends to mirror the national average. Very small volumes are produced in Wairarapa and Otago and so the price information is less consistent. For the other regions the pattern revealed for other varieties is maintained, with Marlborough earning consistently above-average prices and Gisborne earning below-average prices.

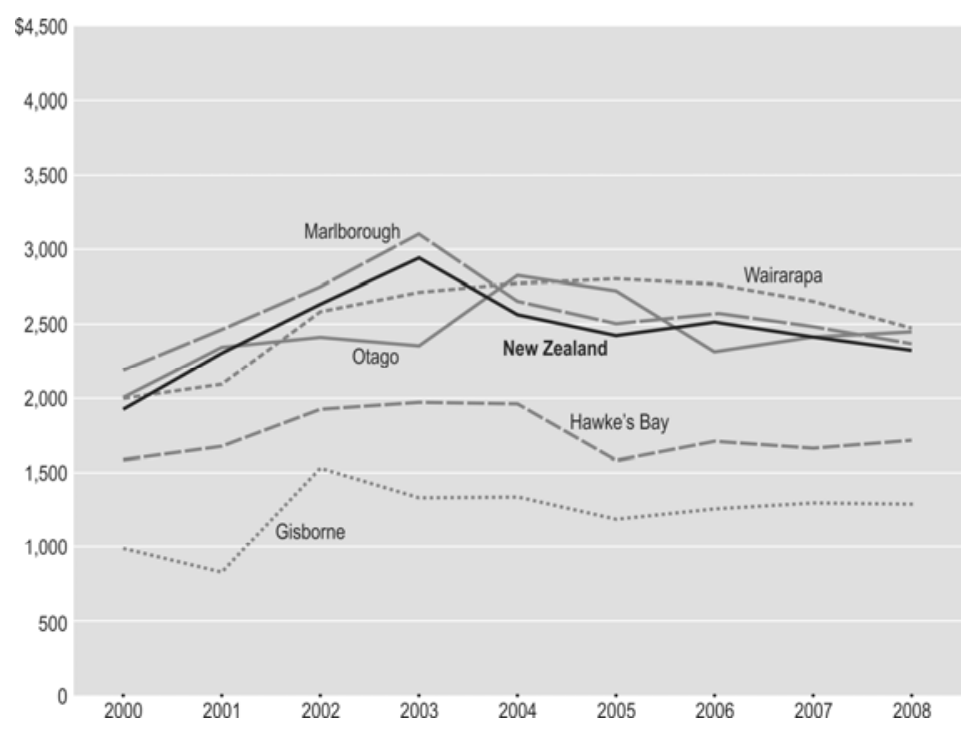

Figure 5: Prices for New Zealand Sauvignon Blanc Grapes by Region, 2000-2008 adjusted to constant, 2008 dollars.

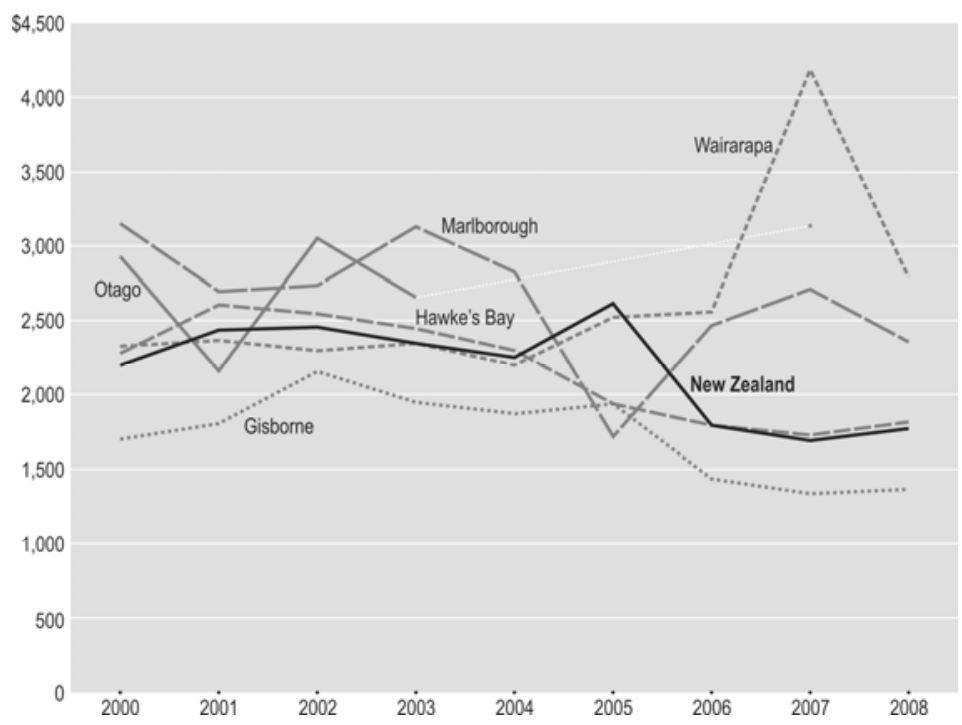

Figure 6: Prices for New Zealand Merlot Grapes by Region, 2000-2008 - adjusted to constant, 2008 dollars.

For each of these four grape varieties the average price data appears to reveal persistent differences between New Zealand's wine regions, with a general trend that Marlborough and the two smaller but highly-regarded regions earning higher returns for their grapes. Gisborne on the other hand, appears to earn consistently lower prices even for the same grape varieties in the same time periods. These findings provide objective evidence for regional differences that many industry observers recognise already. 
There remain of course other variables that may affect regional grape prices. For instance, the analysis above has made no account of differences in grape yields. Yields are revealed in grape volumes per area of harvest land, and so are important measures of land productivity. As with other horticultural crops, grape yields are a function of environmental conditions such as the availability of heat, sunlight and water in the growing periods, as well as soil fertility and the impacts of pests. However, they are also a function of practices in the vineyards, from initial vineyard establishment (choice of variety, clone, trellising, vine spacing, inter-row grassing and so on) to annual practices of leaf plucking, fruit thinning, irrigation and so on. These factors will impact on year-on-year yields, and indeed offer growers opportunities to alter yields in response to price signals and changing demands from wineries in response to grape qualities. Growers can operate strategically in managing yields to effect short and longterm revenue. Nonetheless, vineyard investments are long-term and many aspects of vineyard set-up are more or less fixed investments. These fixities impose both a firm and regional imprint and certain path dependencies that lock in inter and intra-regional diversity especially given the regional patterning of the development of the New Zealand industry (see Moran 2000, Gwynne 2006).

Yields are strongly affected by both artificial and natural factors and will inevitably have geographic variations, and hence we may expect regional differences. We may adjust for the effects of yield in this analysis by converting the price data from a measure of grape volume to one that measures land area to produce a standard volume. This information is not found in published form but is easily calculated from the grape price data, grape production volumes, and vineyard areas. The following, simple algebraic transformation derives a measure for average returns per hectare for a specific grape variety, where $\mathrm{r}$ denotes region and $\mathrm{g}$ denotes grape variety:

$$
\text { Land value }(\$)_{r, g}=\left[\text { Price }(\$ \text { per tonne })_{r, g} \times\left(\frac{\text { Total output }(\text { tonnes })_{r, g}}{\text { Total area }(\text { hectares })_{r, g}}\right)\right]
$$

This measure reveals the regional differences in land values - as measured in terms of grape earning per unit of land area. Since the measures vary for grape varieties and time periods it necessarily provides further evidence of the value of the region to this industry.

In Figures 7-9 the grape returns per hectare (land) are reported for chardonnay, sauvignon blanc and merlot, respectively. A three-year moving average is used to ameliorate the variability between vintages. As before the interpretation should focus on the persistent regional differences rather than the absolute differences in any particular year. Only the three largest grape-growing regions are included owing the distorting effects of the small vineyard areas in Wairarapa and Otago.

In all three cases revealed in Figures 7-9 Marlborough appears to earn substantially more per hectare than the other two regions - even allowing for seasonal variations. Interestingly, Gisborne appeared to earn higher returns than Hawke's Bay until recently. This runs counter to the previous results shown in Figures 4-6 and indicates that Gisborne's higher yields go some way to overcome its brand disadvantage. The significant conclusion of regional differences in grape returns per hectare information is to support the proposition that Marlborough has successfully leveraged greater value even when controlling for grape variety and yields. Moreover, it appears to have achieved this even for two varieties for which it has no special reputation, chardonnay and merlot. 


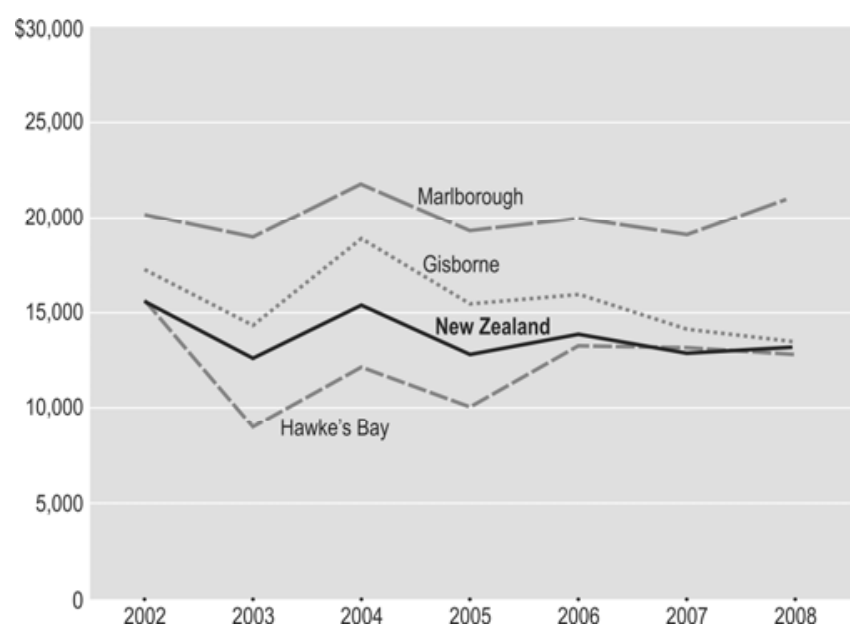

Figure 7: Returns per hectare for New Zealand Chardonnay by Region - using a threeyear moving average for constant, 2008 dollars.

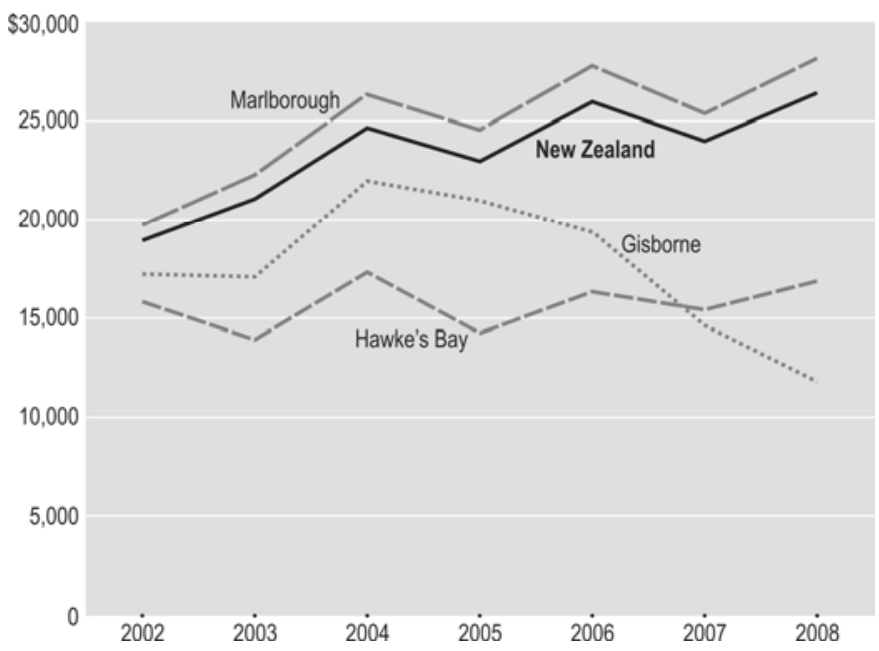

Figure 8: Returns per hectare for New Zealand Sauvignon Blanc by Region - using a three-year moving average for constant, 2008 dollars.

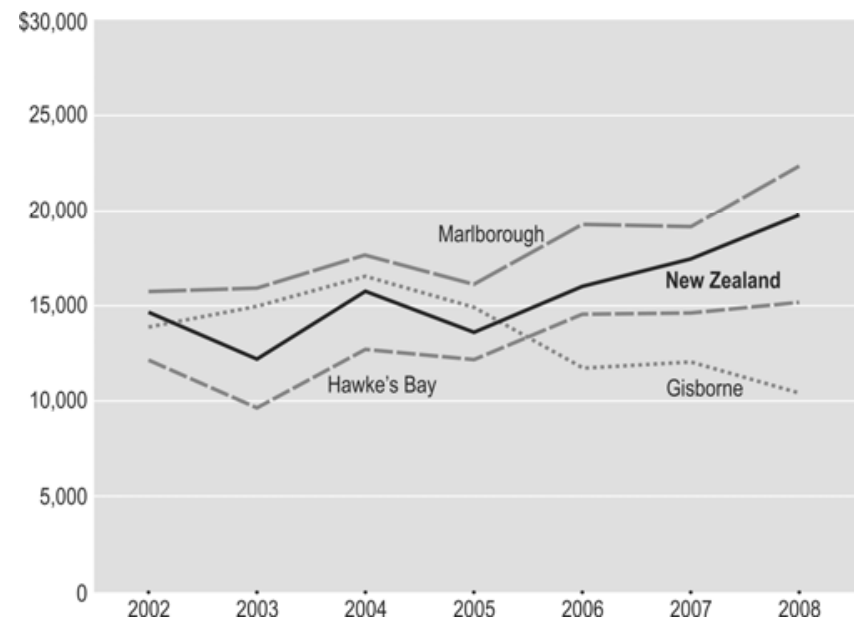

Figure 9: Returns per hectare for New Zealand Merlot by Region - using a three-year moving average for constant, 2008 dollars. 


\section{Industry Recognition of Geographic Brands}

The mission of the national industry organisation, the New Zealand Winegrowers (NZW) is to represent and promote the interests of the industry, and support research. Increasingly, marketing and market research have become prominent activities, and 16 of its 32 permanent employees now have explicit marketing designations. It carries out its marketing activities behind a national brand, which seeks to capitalise on the brand equity built by positive representations of New Zealand and associations between these representations, New Zealand wines, and representations of wine quality built around New Zealand wines. With terroir a master discourse of wine culture, and wine consumers and supply chain intermediaries seeking out associations between wine and place and knowing wines through such referents, this brand equity has been extremely valuable in establishing New Zealand wines internationally. It has been carefully crafted through the production of brand collateral, trade shows, wine media visits, and generic marketing programmes. Over the period of its rapid growth and emergence onto world markets, New Zealand wine was marketed under the logo 'Riches of a Clean Green Land'. This became the banner behind which national environmental aesthetics, narratives of particular winemakers, firms, and regions, and growing reputations for distinctive and high quality wines were configured into a national reputation that allowed New Zealand wines to achieve the highest average prices of any national wine offerings on UK markets.

In 2006, with export volumes increasing rapidly and with them NZW levyfunded incomes and marketing activities, the NZW audited their Riches of a Clean Green brand. They were concerned with their exposure to claims about carbon footprints and other potential risks to environmental integrity. The expensive audit produced a new logo, in keeping with wider national tourism (100\% Pure) and knowledge economy (New Zealand New Thinking) brands. The new brand 'New Zealand Wine: Pure Discovery' is packaged in a livery that connects more directly with national branding colours (black and white) and to the familiar motif of the fern. The new brand was to draw attention to newness, innovation, discovery, and freshness and intensity in the wines. The brand audit confirms the significance of national branding to the industry. In 2009 brand promotion activities included 87 events (seminars, new releases, showcases, trade shows) were conducted in a total of 34 cities across eleven countries. Events included a significant presence at wine shows in London, Sydney, Melbourne, and Tokyo, and organising in-bound wine media events and the Air New Zealand Wine Awards, and organising and or sponsoring high profile domestic seminars attracting international supply chain intermediaries (wine buyers, distributors and media).

Brand New Zealand wine and the efforts to promote it confirm the need to continuously safeguard and re-craft the geographical associations underlying geographical rents. Each of New Zealand's wine regions in turn has its own industry association representing growers and wineries. Each recognises a distinctive regional charter, significant on which is regional marketing - not just facilitating collective sales but developing regional brands for domestic and international markets. These organisations organise a similar range of events, at a smaller scale in terms of event but at a far more fine-grained scale in terms of geographic association. Regional associations have created regional brands that seek to create or safeguard geographic rents. They regularly stage domestic events and occasionally stage international events (often in conjunction with Brand New Zealand Wine), run wine tourism support services such as wine maps, trails and signage, and generate significant regional brand collateral. They circulate and create new place based narratives about regional wines, 
actively cultivating geographical rents. Perhaps most interestingly, regional associations have organised responses to the call from NZW for regions to define and map sub-regional geographical indications (GI) for registration on the EU GI register. The regions now have more or less carefully crafted sub-regional statements of association between place and wine that link discourses of terroir to brand collateral such as logos, narratives and attractive maps. Multiply layered (and scaled) referents to place are seen as adding new qualities to the wine and new substance to the story of wines that can be narrated to enhance the product and compete at points of sale and in the highly competitive game of attracting attention from intermediaries. Each is active intervention to craft geographical rents.

Perhaps the most active in terms of regional brand promotion is the Central Otago Winegrowers Association (COWA). In addition to the website services (including maps, notice boards, sales information, photographic promotion of region, news of awards, regional histories and statements about region), communication services, labour supply services, technical services and research commissioning, regional marketing programmes, and regional lobbying practised by other regions, COWA has established a promotions company that runs its own trade shows and communications campaigns. Its aim is to create and realise value from the place values of Central Otago - to sustain and promote place values and to facilitate the individual wine enterprises of its members. The rents that it creates and stewards have collective components, but also dimensions that different enterprises are more or less able to enhance and realise.

At the level of the individual firm, enterprises create their own place-based narratives and brand collateral. The brand names of wines, their labels, and the stories woven around the wines invariably rely on place references. Place references, from their minimalist form of a statement of origin on a bottle to label liveries, the media attention focussed on wines and their makers, and the more or less elaborate stories told by the enterprises themselves on websites, are very much part of the product. That is to recognise fully the significance and origins of regional rents, it is important to grasp the special significance of wine as a social and a positional good. It is a branded product, with the brand made up in large part by reference to place. It is commonly consumed (and very often purchased) socially, especially in the price and market segments occupied by New Zealand wines. Enterprises commonly talk of the terroir in which their grapes are grown making reference to established signifiers of quality: limestone, free draining soils, and in New Zealand daytime heat and cool nights. Some of these signifiers are universal and utilised to express beliefs that particular soils and climatic qualities impart particular qualities into the wine. Enterprises also tend to emphasise the local, reflecting the more subtle recognition that different mixes of environmental, edaphic and physiological qualities (varieties/clones) can produce different qualities of value.

As one example, small Waiheke Island enterprise Destiny Bay Vineyards, which claims to make New Zealand's most expensive wines, also makes the claim that 'the special gift of Waiheke is its impeccable sense of place'. This is interpreted as a climate that is 'never too hot and never too cold' with the islandness of the climate drawing cooling sea breezes up the natural waterways and valleys in the evenings to replace the rising warm air; and 'a meter thick layer of weathered Aeolian sediment that cracks, shrinks and expands with the change of seasons'. As a result, the enterprise claims, 'there is never panic among the vines ... nothing to distract them from their pursuit of perfection' even though the 'harsh soil' tests the survival of the vines. The vines 
answer the call and yield fruit with distinctive character, flavor and structure, yielding 'grapes with balance, structure, rich varietal flavors, and ripe tannins'.

There is much still to be written about exactly what aesthetics are brought into play (and where and why) in the nature of the place-based stories told about wine. Our interest here, however, is that these aesthetics and associated practices exist and that they create from the consumption end the geographical rents that we identify through grape prices. We identify in the performance of the wine enterprises the brand crafting practices that relate production to consumption and create and recreate geographical rents in the case of positional goods.

\section{Summary - Identifying the Geographic Brand Rent}

In this paper we have pursued the argument that geographic origin forms a discrete and measurable component of the fine wine commodity, and given the specific contribution of this factor we have termed this geographic brand rent. Brand rent matters because it is a discrete value component in addition to the returns to capital and rewards for labour, and in this form it explains the different value of regions. In focusing on grape prices we capture differential values of this intermediary good and so avoid the effect of winery brands, which would necessarily influence the values of finished wine. The comparative analysis controlled for the effects of grape variety and yields - the latter being determined by both environment and craft - in order to expose the geographic factor. The evidence for New Zealand wine is that persistent regional differences exist in both grape prices and the returns per unit of vine-growing land. Of the major wine regions Marlborough clearly earns greater value for its grapes. Within these results we acknowledge that other factors will be influential, and especially the individual production strategies of the wineries. Nonetheless, despite the additional sources of variability the strength of the regional differences are firmly revealed.

Through its formal industry organisation the New Zealand wine industry has expended great efforts to develop and promote a national wine brand. Even while the regional differentiation exposed in the foregoing analysis would be generally recognised within the industry it is not clear that NZW itself has sought to promote regional differences. Most likely this reflects the influence of the large, national wineries - each of which sources grapes from the main regions - and the mandated responsibility of the organisation to represent the whole industry. However, as the industry's production centre of gravity has shifted south so has the brand identity of New Zealand wine been increasingly associated with the Marlborough region.

In a sense the findings of this analysis will accord with well-known patterns within the New Zealand wine industry. It is well known for instance - and discussed in our previous study - that the national wineries have regarded Marlborough as a strategic asset (Hayward and Lewis, 2008), and so we anticipated that regions would be valued differentially. However, in the present analysis this geographic brand rent is revealed and given a monetary value. Ultimately its existence owes much to preferences of wine consumers - who necessarily fuel the value chain by paying premiums for geographically differentiated wines. In this analysis that premium appears to trickle down the value chain, and emerges as a discrete rent on the geographic factor.

\section{References}

Alchian, A.A. (2008), 'Rent', in S.N. Durlauf and L.E. Blume (eds), The New Palgrave Dictionary of Economics (Basingstoke: Palgrave Macmillan). 
Banks, G., Kelly, S., Lewis, N. and Sharpe, S. (2007), 'Place "from one glance": the use of place in the marketing of New Zealand and Australian wines', Australian Geographer 38:1, 15-35.

Barker, J., Lewis, N. and Moran, W. (2001), 'Reregulation and the development of the New Zealand wine industry', Journal of Wine Industry Research 12:3, 199-222.

Benjamin, B. and Podolny, J. (1999), 'Status, Quality and Social Order in the California', Wine Industry Administrative Science Quarterly 44:3, 563-589.

Beverland, M. B. (2005), 'Crafting brand authenticity: The case of luxury wines', Journal of Management Studies 42:5, 1003-1029.

Bourdieu, P. (1989), 'Social Space and Symbolic Power', Sociological Theory 7:1, 1425

Frank, R. (2008), 'Should public policy respond to positional externalities?', Journal of Public Economics 92:8-9, 1777-1786.

Gwynne, R. (2006), 'Governance and the wine commodity chain: Upstream and downstream strategies in New Zealand and Chilean wine firms', Asia Pacific Viewpoint 47:3, $381-395$.

Hayward, D. and Lewis, N. (2008), 'Regional dynamics in the globalising wine industry: the case of Marlborough, New Zealand', The Geographical Journal $174: 2,124-137$.

Lewis, N. (2008), 'Constructing economic objects of governance: The New Zealand wine industry', in R. Le Heron and C. Stringer (eds), Agri-Food Commodity Chains and Globalising Networks (Aldershot: Ashgate), 103-120.

Moran, W. (1993), 'The wine appellation as territory in France and California', Annals of the Association of American Geographers 83:4, 694-717.

Moran, W. (2000), 'Culture et Nature dans la Géographie de l'industrie Vinicole Néozélandaise', Annales de Géographie 109, 525-551.

NZ Winegrowers (various), Statistical Annual, New Zealand Winegrowers, $<$ http: \www.nzwne.com>, accessed 25 April, 2009.

NZ Winegrowers (2009), Annual Report, New Zealand Winegrowers, $<$ http: \|www.nzwne.com>, accessed 21 November, 2009.

Perrouty, J. P., d'Hauteville, F. and Lockshin, L. (2006), 'The influence of wine attributes on region of origin equity: An analysis of the moderating effect of consumer's perceived expertise', Agribusiness 22:3, 323-341.

Schamel, G. (2006), 'Geography versus brands in a global wine market, Agribusiness 22:3, 363-374.

Schamel, G., and Anderson, K. (2003), 'Wine quality and varietal, regional and winery reputations: Hedonic prices for Australia and New Zealand', Economic Record 79:246, 357-369.

Thrane, C. (2004), 'In defence of the price hedonic model in wine research', Journal of Wine Research 15:2, 123-134.

Tustin, M., and Lockshin, L. (2001), 'Region of origin: Does it really count?', Australia and New Zealand Wine Industry Journal 16:5, 139-143.

Unwin, T. (1999), 'Hedonic price indexes and the qualities of wines, Journal of Wine Research 10:2, 95-104.

Vaudour, E. (2002), 'The quality of grapes and wine in relation to geography: Notions of terroir at various scales', Journal of Wine Research 13:2, 117-141. 